\title{
TOWARDS A NEW NATURAL THEOLOGY BASED ON HORIZONTAL TRANSCENDENCE
}

Author:

Cornel W. du Toit ${ }^{1}$

\begin{abstract}
Affiliation:
${ }^{1}$ Research Institute for Theology and Religion, University of South Africa, South Africa
\end{abstract}

\section{Correspondence to:} Cornel W. du Toit

e-mail:

dtoitcw@unisa.ac.za

\section{Postal address:}

PO Box 780, Groenkloof, 0027, South Africa

\section{Keywords:}

natural theology and anthropology; humans in an immanent frame; human condition and place of death in theology; horizontal transcendence; vertical transcendence

\section{Dates:}

Received: 29 Apr. 2009

Accepted: 25 May 2009

Published: 12 Aug. 2009

How to cite this article: Du Toit, C.W., 2009,

'Towards a new natural theology based on horizontal trancendence', HTS Teologiese Studies/ Theological Studies 65(1), Art. \#186, 8 pages. DOI: 10.4102/hts.v65i1.186

\section{This article is available} at: http://www.hts.org.za

(C) 2009. The Authors. Licensee: OpenJournals Publishing. This work is licensed under the Creative Commons Attribution License.

\section{ABSTRACT}

This article explores a context for designing a new natural theology. The starting point is that traditional developments in this regard, from Augustine to Aquinas, Paley, Boyle and Barth, do not get us much further. Our thinking reflects our world - a world which has changed dramatically under modern and postmodern influences, especially those of the sciences. A new natural theology is simply an account of nature and creatureliness with due regard to scientific advances. Consequently natural theology today must start 'from below' with a new anthropology that reflects the worldview of our time. As a result the article rejects absolute transcendence, replacing it with a horizontal transcendence that accords with humans' biological makeup and with presentday scientific thinking. In the framework of horizontal transcendence the pivotal problem of the human condition is no longer death, but life. This has radical implications for theological thinking. The example used in the article is the impact this has on Paul's theological method. Examples of theology centring on the problem of life are discussed briefly with reference to Girard, Žižek and Vattimo.

\section{INTRODUCTION}

We interpret the world to make sense in terms of present knowledge. There is not just one interpretive model but many - especially in the area of religion. This article focuses on some aspects of current attempts at devising a new Christian natural theology.

A 'new' natural theology is not something that can be imposed artificially from above, in a constructivist-fashion. It springs spontaneously from below via the multitude of theories associated with our techno-scientific, social and other development. Here we concentrate on how these forces have changed our understanding of transcendence and immanence. Our view of transcendence determines our altered attitude towards the supernatural. When the concept of transcendence changes, so do our acceptance or non-acceptance of it and our understanding of the supernatural.

Transcendence is a relative concept. We confine it to the difference between radical (vertical) transcendence and horizontal transcendence. The meaning underlying transcendence is that which lies beyond (human knowledge, experience, control). But transcendence is not necessarily limited to what lies beyond space and time, outside and beyond us. In religion, God, the transcendent, is transposed beyond space and time. Unlike human beings, he is not bound by these dimensions. Transcendence may be part of our metaphysical thinking or it may relate to our experience of the transcendent - a radical experience of something that irrupts into human life from 'outside'. Existentially it always entails a relationship with the transcendent - be it awe, fear, enlightenment or mysticism. Hence the experience of transcendence is immanent, mediated by human physicality and historicity. The grand metaphysical concepts usually associated with transcendence, such as God's immortality, immutability, omnipresence and omniscience, are at most background assumptions in the experience of transcendence. Humans apparently need to express that experience in language that surpasses their day-to-day reality; hence the predilection for metaphysical terminology, metaphor, symbolism and mystical language.

Transcendence has to do with double vision, which discerns something beyond physical everyday events. To cite a biblical example, Jacob had a dream at Bethel (Gn 28), which he interpreted as a divine revelation. In another instance the few survivors in the village whose population was wiped out by a plague (and who saw it as God's punishment for their sins) spoke in whispers in the house lest God hear them and discover there were still some left alive (Am 6:10). McGrath (2006:69) mentions the example of Samuel, who hears God's voice calling him and thinks each time that it is Eli, until Eli tells him it is God's voice. Thereupon he interprets the voice differently and encounters God.

Thus immanent or horizontal transcendence puts the accent on the human situation in which transcendence is experienced. Our closed reality is never closed - it always confronts us with openness and unpredictability.

Transcendence is the experience of the $\mathrm{O} /$ other, of differentness, différance. But it can also be an experience of identity and union (AUB), depending on the situation. Autonomous human beings may rest content with their self-contained reason without grasping for the supernatural. But they may also resort to sources other than and analogous to reason for the sake of fulfilment. Rationality alone does not necessarily ensure satisfactory explanatory systems. Taylor puts it thus:

Reason by itself is narrow, blind to the demands of fullness, will run on perhaps to destruction, human and ecological, if it recognizes no limits; is perhaps actuated by a kind of pride, hubris. There are often echoes here of a religious critique of modern, disengaged, unbelieving reason. Except that the sources are not transcendent. They are to be found in Nature, or in our own inner depths, or in both.

(Taylor 2007:9) 


\section{The dead-end street of method in designing a natural theology}

There is simply no universally accepted, scientifically substantiated method of designing a contemporary natural theology. In fact, it is by no means clear what natural theology is today - which makes it difficult to redesign it. The best way is to use historical examples of what it used to be, then inquire into what, if anything, it is today, and then consider whether it is possible to redesign it.

The approach currently adopted in the science-theology debate appears to be postfoundationalism, operating on the lines of critical realism (see especially Van Huyssteen's work). The problem is that there is far more talk about approaches and methods than concrete examples of how these function in practice. Thus it is one thing to maintain, for instance, that rationality is biologically embedded, but quite a different thing to demonstrate that consistently in our thinking. In his approach to natural theology McGrath (2006:11) rejects the foundationalist rationality of the Enlightenment along with leftist postmodernism, which he considers anti-realistic. ${ }^{1}$ McGrath adheres quite closely to Barth's approach (see Myers 2006:13n, 16, 17n). Foundationalism must be rejected because it tends to give rise to fundamentalism, creationism and controversies such as the intelligent design debate. Postmodernism, on the other hand, is considered dangerous because of its excessive relativism, which sees everything as relational. Postfoundationalism incorporates critical realism and seeks to maintain a balanced position in-between the extremes.

Why do we still consider it necessary to link (even restrict) God to creation? It is understandable if people who have no theory of the origin of ontological reality do so. But considering the scientific explanations we have today the God-creation connection is no longer self-evident and, ever since the Enlightenment, it has often resulted in deism. A better option is to see God in terms of evolution theory as a 'sustainer' engaged in ongoing creation (with humans participating as co-creators). After all, the connection remains metaphysically important, since one needs to account for the origin of ontology. But does that not restrict God to Greek philosophy (First Cause, Unmoved Mover)? Besides, in day-to-day life creation is the background to our existence and reality is governed by interaction between our inner mental world and the other in the world outside (see reality in DuToit 1984:173-183)

When it comes to the doctrine of God there is a definite move away from a metaphysical God concept (with Greek and neo-Platonist influences) towards emphasis of the incarnate God. Also, Moltmann's suffering God who shares humankind's existential angst contrasts with the Platonist God's self-contained introversion (logos endiathetos), of which we merely experience feeble reflections (logos spermatikos), with the resultant Gnostic devaluation of the biological dimension. Not only have Aquinas's so-called proofs of God's existence fallen into discredit, but our insight into God-talk and the nature of language means that what can be said about God is couched in this-worldly images and metaphors (Du Toit 1984). A negative or apophatic theology does not help either, for it merely affirms the unknowability and ineffability of God. A cataphatic theology, by contrast, is positive in that its point of departure is God's incarnation in Christ, something one can speak about (although here, too, the apophatic dimension pops up selectively). There are several models that prevent the domestication of an incarnate God by the human mind, the most promising being the concept of incarnated or horizontal transcendence. Many people today do not find it counter-intuitive to link God with creation (also read science), but do consider it counter-intuitive to see him as the cause of crises in their personal lives.

1.The statement is debatable. Myers (2006:11) rightly observes: 'Although McGrath's critique of postmodern anti-realism is useful, at points it exhibits an insufficient appreciation of poststructuralist insights and a failure to engage seriously with appreciation of poststructuralist insights and
poststructuralist thinkers on their own terms.'
First we need a thumbnail sketch of the history of the origin of religion. All religions started out as nature religions, which vested early societies' interpretation of powers and forces with a form of transcendence. They were followed by revelational religions that were largely a reaction against so-called nature religions. This situation prevailed until the scientific revolution, which ushered in a new phase of natural theology that initially evolved in tandem with revelational religion and was then transformed into dualism with its two books (the book of nature and the book of revelation), each offering a different slant on reality. In due course the two-books approach evolved into a book of facts and a book of fiction, the latter being the revelational religions that still operated in a text with an outdated worldview. ${ }^{2}$ Since then the book 'from above' has defended itself against new insights offered by the sciences.

There is no shortage of highly specific theologies, but they interact more meaningfully with philosophy than with present-day science. Still, modern thinking rubs off on theology. Theologising is a relational activity characterised by the design of metaphysical systems. Whereas our forebears at the dawn of history used religion to make sense of natural events, we now have the reverse. It is no longer religion that imparts meaning to nature: nature makes religion meaningful. Fresh insight into nature (science) is used to make creeds credible in a techno-scientific age.

Classical English natural theology (Boyle, Bentley, possibly Paley) traditionally defined natural theology as the enterprise of providing support for religious beliefs by starting from premises that neither are nor presuppose any religious beliefs' (McGrath 2006:67, quoting Alston). It is an approach from below which, in light of natural realities, draws reflective contours and interprets facts in a way that allows God's face to emerge.

The question is whether traditional Christian natural theology, more especially its claim to exclusiveness, is still relevant today. McGrath does not question the relevance of tradition and sets the following conditions:

For a natural theology to be Christian, it presupposes and articulates such notions as the Trinity and the incarnation - and thus moves decisively away from the "common sense" Deism of the Enlightenment.

(McGrath 2006:92)

McGrath (2006:93-94) is sceptical about the notion that humans are critically detached observers of nature. That is the traditional approach in natural theology as articulated in the Boyle lecture, and it is influenced by Enlightenment thought. McGrath's criticism is based on the idea that if humans are observers of nature as their object and they observe God in nature, then God, too, is reduced to an object. "These assumptions led to human observers becoming elevated to subjects and God demoted to object by the rise of science in the seventeenth and eighteenth centuries' (McGrath 2006:94). To McGrath, the challenge of designing a natural theology today lies in restricting its explanatory aspects.

The challenge, then, is to develop a Christian approach to nature - that is to say, a natural theology or a theology of nature - which is not limited to intellectual or explanatory aspects (McGrath 2006:96).

The question is whether a mere act of the will can confine intellectual explanation to McGrath's approach, which prefers to put the accent on tradition and spirituality. After all, what aspect of Christian doctrine is not shaped by intellectual explanation? What he says about natural theology is equally applicable to every Christology or doctrine of God.

2.In sharp contrast to this view, Myers (2006:6) cites the following opinion by McGrath 'In contrast to the modern notion of natural theology, McGrath affirms that nature, autonomously considered, cannot serve as a foundation for theological reflection - or, indeed, for any kind of reflection, since "nature" is itself always a constructed concept.' As if theology, like any view of nature, is not also a constructed concept shaped by the insight and interpretive forces of a particular age. 
Despite the taboo, the cardinal question in natural theology is that of method. ${ }^{3}$ How do we set about it? Do we start with revelation and tradition, with nature, or with a combination of these? If we start with revelation, to what extent may we reinterpret it in the light of nature? And if we start with nature, can it be used as a proof of God's existence that embraces the entire phenomenon of God and religion, hence be universally relevant? (If one starts with revelation, one can only lay claim to the authenticity of a specific religion). But we no longer start with nature as Aquinas did in his day. Nature as an uninterpreted entity does not exist - not even if we confine ourselves to its aesthetic beauty. Hence when we speak of natural theology we are not starting with nature an zich, but with nature as already interpreted by the sciences. ${ }^{4}$ These are the sciences that have changed our perception of space and time; that offer a new understanding of creation; that explain the evolution of life, the operation of the brain in clarifying our experience, and the rest of it.

Conversely, of course, we do not start with revelation an zich, but with revelation as interpreted by the church and theologians. Hence the natural theology we want to design is really a scientific faith (more correctly, according to scientists, starting with facts rather than with faith). This means linking science to transcendence in light of selected parts of revelation, inasmuch as that is possible. Notable examples of this approach are the discredited anthropic principle (Peacocke 1993), quasi-scientific intelligent design theory (Johnson) ${ }^{5}$, quantum physics (Peat \& Hiley 1987), and electromagnetism (Pannenberg 1993). There are also lots of views in between, ultimately confirming scepticism about any method.

The fact is we are always looking for the holy grail that offers a way out of our dilemma. Usually it takes the form of a single concept or theory that must explain everything. In most cases the approach suffers from petitio principii, when we prove what is already present in our assumption. Examples are the following: Faith is biologically rooted. Of course all human activity is biologically rooted (although it would seem that human thought, an epiphenomenon of brain processes, exceeds pure physicality). Of course scientific thinking is also biologically rooted and both theology and science are rational activities - but that does not help us one iota. Rationality in religion remains based on religious assumptions, which are improvable. In practice religion depends far more on factors that support rationality such as emotion in the form of finding meaning, guilt feelings, remorse, willingness to forgive, hope and the like. Even if some of these factors play a role in science, it is not openly admitted and they play no role in, for instance, theory building. Other examples are the connection of religion with health, instances of the operation of the brain and cognitive science, the metaphoric dimension of language and its transcendent nature that is discernible in both theology and science.

\section{A new natural theology based on an anthropology of biologically determined humanism}

The intention is not to construct a new anthropology but to identify the extent to which anthropologies (for there are more than one) change under the influence of a shared worldview and social factors. Our self-perception changes as our view of our environment changes. Elias confirms this:

3.Myers (2006:3) points out that McGrath likes to claim scientific methods for theology, but not necessarily the findings of science. He cites McGrath's view that '[a] theology which is grounded in any particular scientific findings will inevitably become outdated as scientific knowledge develops, whereas a theology that is related to science methodologically may be of lasting value'. As if method and findings are separable! As if the findings of a theology based on scientific methods cannot become dated too!

4.Although McGrath concedes that our view of nature is determined by our interpreted construction, he dos not apply it in his design of a natural theology. Mc reth falls back on revelation as if it is totally free from human constuction. Huth falls back on revelation as if it is totally free from human construction. Human constructions invariably feature in the worldview of a particular age - the Bible offers innumerable examples. Nonetheless McGrath invokes revelation and tradition as if
The problem of "facing oneself"...plays its part in explorations of nature as well as in those of society. For humans form part of both. Every major change in people's conception of nature, therefore, goes hand in hand with a change of the picture they have of themselves.

(Elias 1987:79n)

This is analogous to Taylor's comment on the design of epistemological developments:

It isn't just that one day people looked without blinkers and discovered epistemology; rather this is the way things could be made to look from within a new historical formation of human identity, that of the disengaged, objectifying subject. The process involves a reinvention, a recreation of human identity, along with great changes in society and social practices.

(Taylor 2007:560)

In this context the influence of the sciences helped to shape a new anthropology. Our self-image has changed radically in recent times as a result of new insight into our biology and the biological orientation of our overall anthropology. Hence it makes sense not to base a contemporary natural theology on a doctrine of exclusive revelation, a philosophical anthropology or even objective nature, but to start with anthropology. Of course, the holy grail contains wine from all those vineyards!

Theology cannot be separated from anthropology. Science is intrinsically linked with anthropology. Yet there is no 'pure' anthropology that offers a connecting link, any more than there is 'pure' nature or 'pure' science. So if we proceed from our interpreted self and wade through all the theories, we will scrutinise the phenomenon of thinking, believing human beings and then inquire into our interaction with one another wearing our scientific hat. Hence our point of departure is modern, secularised, techno-scientific humans and their questions. Here we rely mainly on the work of Charles Taylor (2007).

The premise is that societies, although diverse, are marked by common factors that influence everyone and, while they do not create unanimity, they make it possible to understand the other's point of view. A good example is the recent controversy between believers and 'atheists' (Dawkins, Dennett, Claassen and others). The dialectics should be seen in context and be interpreted positively. After all, atheism is dialectically dependent on faith and cannot exist in a vacuum. The debate is to be welcomed, moreover, since it is more beneficial than a situation in which people are simply uninterested in a religion that leaves them cold. Besides, the church itself had a hand in creating a climate that gave birth to atheism:

Now this adversarial picture of the relation of faith to modernity is not an invention of unbelievers. It is matched and encouraged by a strand of Christian hostility to the humanist world.

(Taylor 2007:569-570)

He cites the example of Pius IX, whose Syllabus of 1864 vehemently attacks the errors of the modern world: human rights, democracy, equality and the like - things without which the modern state would be inconceivable. The world that gave birth to atheism was made by believers and unbelievers alike.

And it is clear that there are many people of faith who have helped to build and are now sustaining this modern humanist world, and are strongly committed to the modes of human well-being and flourishing that it has made central.

(Taylor 2007:570)

We have to concede Taylor's point (2007:565) that science is not solely to blame for atheism. We need to take cognisance of all the cultural developments that influence us imperceptibly.

What was once one possible construction among others sinks to the level of picture, in Wittgenstein's sense; that is, it becomes part of the unquestioned background, something whose shape is not perceived, but which conditions, largely unnoticed, the way we think, infer, experience, process claims and arguments.

(Taylor 2007:565) 
The model we are looking at here - incarnated transcendence - is not just atheistic or exclusive humanism in disguise, which is no more than materialism with a dash of moral sauce. Horizontal transcendence is exactly what it says: wholly immanent, but at the same time radically transcendent. It is not dualistic, but describes the mobility of the human mind, rooted in its biology. Let us take a look at it.

\section{Aspects that locate modern humans in an immanent framework}

The distinction between natural and supernatural, or transcendence and immanence, only became current in the late Middle Ages as a product of Latin Christianity (Augustine) it would have been inconceivable in the enchanted world of early civilisations. That world may be regarded as a kind of transcendent immanence - which naturally differed radically from present-day transcendent immanence. It saw nature as animate, both awesome and dangerous. The purpose of the distinction between transcendence and immanence initially was to 'protect' transcendence and affirm the autonomy and otherness of the transcendent order (Taylor 2007:429, 542).

Horizontal or incarnated transcendence - one could also call it open (as opposed to closed) immanence - not only refers to the autonomy of self-contained, 'buffered' humans with their instrumental reason, but also to the notion that explanations must be found in natural rather than supernatural forces. The argument is not that horizontal transcendence replaces vertical transcendence, but that nowadays they coexist. This is encapsulated in Bruce's definition of religion (quoted in Taylor):

Religion for us consists of actions, beliefs and institutions predicated upon the assumption of the existence of either supernatural entities with powers of agency, or impersonal powers or processes of moral purpose, which have the capacity to set conditions of, or to intervene in, human affairs.

(Taylor 2007:429)

Gianni Vattimo, Slavoj Žižek and René Girard each had his own view of the role of transcendence in religion. They agree, however, that the transcendent is a product of metaphysics - and that it is violent. Transcendence and metaphysics are linked. Both deal in mental constructs that have to meet certain requirements, both have enforceable power, lay claim to reality as it eternally is in itself and thus provide an irrefutable basis. Vattimo, with reference to Heidegger and Nietzsche, insists that "we should "leave behind Being as grounding", we should no longer think of "Being in foundational, or metaphysical terms"' (Depoortere 2008:7). Regarding metaphysics he writes (in The adventure of difference):

With its predilection for unifying, sovereign and generalizing categories, and with its cult of the arché, it manifests a fundamental insecurity and exaggerated self-importance from which it then reacts into over-defensiveness. All categories of metaphysics are violent categories."

(Depoortere 2008:6-7)

The reverse also applies: '...violence is the result of metaphysical thinking, of the belief that one has access to "objective" reality, to reality as it eternally is in itself' (Depoortere 2008:7). Accordingly he accuses the churches' official doctrines of being rigid metaphysical systems. He wants to see a radical demystification of the (in his case, Catholic) church's dogma and morality in the sense of 'the removal of all transcendent, incomprehensible, mysterious and even bizarre features' (Depoortere 2008:13) Vattimo invokes Girard's notion of violence, which he associates chiefly with metaphysical thought. Dilthey (Depoortere 2008:12) pointed out that after the fall of the Roman Empire the Christian church undertook the preservation of classical civilisation and therefore adopted Greek metaphysics. But to Vattimo metaphysics remains violent: 'This metaphysics, like any metaphysics, is...inherently violent, because it is striving "to reach and be taken up into the first principle"'. In other words, metaphysics is a product of the will to power and arises from the human 'desire to own one's existence completely' (Depoortere 2008:12). Vattimo sees the history of Western civilisation as an exodus from the sacred to the secular, ushered in by the incarnation.

\section{The following aspects that locate modern humans in an immanent framework can be identified:}

- Our interpretive framework is always determined by our age. An example is our perception of causality and design, which have assumed specific features since the start of the scientific revolution and since then have undergone important changes (also see Taylor 2007:343). In the enchanted world of ancient religions the sacred was localised in sacred places (temples and shrines), agents (e.g. priests), times (feasts), utterances (religious language), acts (rites), etc. With the advent of the scientific revolution this conception of the sacred made way for causality and design as understood in post-Newtonian science:

Now the presence of God no longer lies in the sacred, because this category fades in a disenchanted world. But He can be thought to be no less powerfully present through His design.

(Taylor 2007:447)

Of course, we know that design theory was misused as an indirect proof of God's existence in the quasi-scientific arguments of Johnson, Behe and others, and the criticism that evoked.

Taylor (2007:551) does not argue for or against an immanent frame of reference but shows how it functions as an interpreted world. Naturally neither objectively provable reality nor faith in an invisible, supernatural reality is independent of human beings, who interpret both facts and faith as such. But there are cultural and other factors that permit an interpretation today that would have been impossible or unlikely in earlier times.

- The human good: 'The human good is in its very essence sensual, earthly; whoever identifies a transcendent goal departs from it, betrays it' (Taylor 2007:547). The modern moral order is based on Taylor's view of human flourishing (Taylor 2007:430). It concerns our culture of human rights, equality, dignity of the individual and the like, the general principle being the common good.

- Sense of awe at the miracle of nature and the cosmic order generally and human evolution from lower forms of nature in particular: that evolution, while undeniably miraculous, remains at a natural, immanent level:

... a kind of punctual hole blown in the regular order of things from the outside, that is from the transcendent. Whatever is higher must thus come about through the holes pierced in the regular, natural order, within whose normal operation there is no mystery.

(Taylor 2007:547)

'Excarnation' of religious life: transposing religion located in external forms and rituals to religion as a mental activity (Taylor 2007:554, 438). This is manifestly the Cartesian tradition and relates to the establishment of the autonomy of individual thought. Translocation of the point of orientation from the concretely physical to the interior mental world should be linked with the disorientation of the earth as the point of cosmic orientation. Two thinkers have to be singled out in the scientific revolution - Galileo and Descartes. The scientific revolution was a revolution in orientation, a shift and re-establishment of centres of gravity. The invention of the telescope shifted the point of orientation from a terrestrial to a cosmic, universal one and Descartes' methodological doubt shifted it from 'objective' reality to discriminating reason. Arendt (1958:279) comments: '... even if there is no truth, man can be truthful, and even if there is no reliable certainty, man can be reliable.' The establishment of the autonomous, discriminating subject is inconceivable without Descartes. The capacity to doubt (dubio ergo sum), like the possibility to falsify, remains an option that people can exercise and that affirms the autonomy of their thinking. 
To Taylor $(2007: 543,545)$ the immanent framework is part of all modern Western people, characterised as they are by a buffered identity and respect for the limitations set by the physical and social sciences (the latter being modelled on the former). The buffered self (buffered by defence mechanisms to safeguard its autonomy) is marked by a distinction between inner/ outer, mind/world as separate loci, and by a rich vocabulary of interiority, 'an inner realm of thought and feeling' (Taylor 2007:542).

The idea of horizontal transcendence or open immanence features in the work of Girard, Vattimo and Žižek. Žižek, for example, sees the incarnation of Christ as the end of God's transcendence (Depoortere 2008:135). Science fiction films depict aliens either as wholly other, monsters you cannot bear to look at, usually a conglomerate of reptile, octopus and machine, or as beings indistinguishable from ordinary humans, hence in ordinary human form (Depoortere 2008:101). Žižek uses this example to describe the God concepts of different cultures. While the pagan gods were anthropomorphic, the Jews 'de-anthropmorphised' their God. The pagans could not understand the rejection and destruction of their god images. 'Pagans did not believe their images to be gods and they did not even believe these images to be, in any way, adequate representations of the gods' (Depoortere 2008:102). To the Jews the prohibition of making any image of God is a focal article of faith. Žižek says this is because an image would make God look like an ordinary person (like aliens who are indistinguishable from people). 'Indeed the Jewish God experiences full wrath, revengefulness, jealousy, etc., as every human being' (Depoortere 2008:102). Christianity fully personalised God in the figure of Jesus Christ. The history of the incarnation is among the earliest instances of immanent transcendence. But to Žižek it represents an irreversible change: it heralded the end of superterrestrial transcendence:

Christ did not come into the world to open a direct communication line between humankind and a God that remains beyond and to whom he returns after his death. No, since Christ, "there is no longer any transcendent God with whom to communicate"'.

(Žižek, quoted in Depoortere 2008:124)

\section{Contours of a new natural theology}

Against this background our point of departure must be to design a hermeneutics of anthropomorphic nature. Anthropomorphic nature is not conceivable without the insight and impact of the modern sciences - not just physical but also human sciences. Nowadays we see and interpret nature through the scientific spectacles we wear. ${ }^{6}$ Indeed, rapture at the grandeur of nature, at both a micro and a macro level, is scientifically mediated in a manner that makes it hard to discern which has the greatest impact. Is our wonderment at nature really made possible by science? Appleyard (1992:228) already pointed out that modern people have replaced faith in transcendence with faith in science. The notion is not at all absurd if one considers to what extent modern people are dependent on science's promise of a good life (prosperity), health (longevity), new inventions that make life even better, and so on. There is also our day-to-day dependence on techno-scientific artefacts without which we cannot imagine our lives (cf. e.g. total dependence on God for all these benefits - see Schleiermacher $\left.{ }^{7}\right)$. Science moreover predicts our apocalypse - both immediate dangers (global warming, pollution, overpopulation) and the long-term fate of our planet,

6.In this regard McGrath (2006:92) emphasises the influence of tradition rather than science as the determinant of our view of nature: '...the enterprise of natural theology rests on a tradition-specific rationality. Reading nature as God's creation is tradition specific, not a universal option. It requires a certain net to be cast over our experience of the world, and a certain quite definite framework to be brought to its interpretation.... [T]he God which natural theology "finds" in the world is already known and characterized by the specifics of the Christian tradition, grounded in revelation.' But how many people still believe this today? The disparity between revelation. But how many people still believe this today? The disparity between worldview is so great that tradition, like nature, is involuntarily seen through scientific spectacles. Whereas the Christian tradition is 'specific', our scientific spectacles are to a great extent universal. even our universe. Our argument, however, is not about our faith in science but about the fact that nature is mediated by science. What we attribute to nature relates to the anthropomorphic way we think about nature.

Modern people, unlike their predecessors, know that they are genetically linked with all forms of non-human life. The accent is not only on that relationship, but increasingly on our interdependence - especially in light of the ecological crisis confronting us. Examples are animal rights; a new emphasis on the interdependence of humans and nature; the 'healing' influence animals exercise on people; the growing number of analogies between humans and their prehistory from the cellular level (autopoietic systems) to the great hominids and the development of the first societies (Boyer, Wolpert, De Waal). Suffering and evil are reinterpreted biologically (see Bennett $e t$ al. 2008).

\section{Secularisation and immanentisation of death and the implications for Christian theology}

Assuming that religion is committed to explanatory systems that help people to make sense of their lived reality, we cannot ignore the worldview and Zeitgeist in terms of which the explanations are offered. Usually they are causally linked with the human condition and our experience of mortality, meaninglessness, suffering and loneliness. In the past explanations of the human condition rarely included its ties with our biological constitution but concentrated on metaphysical, transcendent factors. One could say that, apart from modern physical science, no explanation is purely realistic. Metaphysical explanatory systems (which interact with the designer's contextual experience of her world) are 'logical' and follow a given pattern. We link our human experience of wretchedness, illness, danger, anxiety, insecurity and death to a cause and then look at a metaphysical, transcendent level for answers that accord with the human predicament. As in all 'good' novels, every existential crisis we experience has a happy ending. We appear to be wired to think in a structure of danger and escape from danger. The alternative to that is narrowed down to cosmic tragedy that paralyses optimism and the will to live. The eternal happy ending is our response to the reality of death, suffering, lack of fulfilment, misery, illness and ageing: a transcendent paradisiacal sphere that promises the reverse of wretchedness for all eternity. Thus the human condition is dialectically linked with a happy ending of immortality and a predicament-free heaven where all problems have been resolved and all suffering is over.

The logic of this metaphysical model (finding the cause and resolving the dilemma) is also discernible in the New Testament. Paul, who vividly illustrates the pattern, finds the cause of human vulnerability in sin and the solution in a blissful hereafter, vouchsafed us by Christ's atoning death. ${ }^{8}$ Sin as the cause of death/the human predicament should be regarded as metaphysical. It is the link of sin to evil that makes sin metaphysical. It is far more than human wrongdoing. It is a power to which humankind has been 'sold', a power that has humans in its grip (Paul uses the expression 'sold under sin' $-\mathrm{Rm}$. 7:14). This power is naturally personified by the devil. Sin affects everyone, from infants ${ }^{9}$ to prophets to devout believers - all die, whatever qualities they possess. Sin does not represent specific transgressions, although it includes all of them. Theologically, it must be seen as the natural sense of insignificance and creatureliness people feel when they experience an encounter with the transcendent. ${ }^{10}$

8.Interestingly, the emphasis in the development of Christianity is on exalting the Easter events rather than on Jesus' life. After all, his death has to be linked dialectically with what he lived for, which can be condensed into his recognition and glorification of humanness regardless of cultural convention. For a rejection of the metaphysica grounding of the Easter events (whether in Anselm's theology or Abelard's), see Žižek's ideas (Depoortere 2008:98-100).

9. Hence Augustine's distinction of peccatum imputatum/peccatum inhaerens and the need for infant baptism. 
Paul's genius is that he makes use of a current model and merely gives the solution to the dilemma new content: faith in Jesus Christ, whose resurrection verifies his divine sonship. If you cling to that and believe in it, you will live forever. (Does that mean faith in Christ or in Paul's system?) At all events, the history of Christianity shows how this model evolved into a sophisticated, logically intact metaphysical system - taking into account both Anselm and Abelard and the Wirkungsgeschichte of their ideas. Anselm, who worked out his theology in Cur homo Deus?, builds it on the Roman legal system that has scant support in present-day theology. Abelard in his turn invokes human subjectivity and emotion that is moved by the Easter events and are meant to get people to repent - again a much criticised system.

The point is that the entire Reformed doctrine is based on the principle of sin-redemption-gratitude. It rests on Paul's singling out death as the symbol of the human predicament, sin as its cause and redemption as its solution. If death as the supreme symbol and challenge of the human condition is replaced by life, we need to find a new system on which to base faith in our time. I believe this is possible. It can be done in a way that does not put faith at loggerheads with science but retains biblical concepts as its premise. This approach can be accommodated in a system of horizontal transcendence. If the problem of life is the point of departure, the accent is not primarily on death (which we cannot talk about, since we can't know it) and a transcendent reality beyond the grave, but on life itself. Making life the cardinal problem to be fathomed does not condemn us to an empirically closed worldview, for human thought as such is characterised by a transcendent movement. Part of the problem of life is the human experience of non-fulfilment and desire (see Girard), which at once raises the question of how to transcend it. That evokes the Christian concepts of atonement, forgiveness, acceptance and love that are central in the words and deeds of the historical Jesus. Thus the emphasis shifts from the radically transcendent nature of the Easter events to Jesus' words prior to those events. Theology has put the Easter events centre stage to the extent that Jesus' earthly life is often reduced to background décor. After all, the Easter events would have been pointless if they were not preceded by Jesus' radical humanity.

Immanentisation of the symbols describing the human dilemma, its cause and the solution to it

My underlying assumption is that the symbolisation of the human dilemma as death and mortality do not have the same impact in today's secular world as it once had, partly under the influence of science. Death is increasingly seen as an integral, normal part of human biology. Death as a transcendent reality, personified by angels of death and destructive forces, is immanentised in human biology. If the symbol encapsulating the human dilemma changes, it follows that the causal factors leading to it will be viewed differently. As life (and its problematic nature) replaces death as the master symbol of the human dilemma, its primary cause also has to be replaced (by substituting biological and cultural factors for metaphysical powers of sin). Christ is still seen as the solution to human needs, but in a radically incarnate form. This is happening in certain theological circles at present, inter alia through the development of a secular (public) theology and a new natural theology. The cardinal features of these developments are manifested in an immanentisation of the symbolic cause, consequence and solution to the human dilemma. We consider it briefly.

\section{Shifting the focus from death to life as the problem of the human condition}

We have seen that death as the symbol of the human dilemma makes way for the problem of life (especially in its biological form). It is probably not too far-fetched to connect the death-of-God notion with the death-of-death, in the sense of death

God's grandeur that made him aware of his unclean state (Is 6:5). In this example the experience of uncleanness/sinfulness is a sense of insignificance and creatureliness in the face of transcendence. as a metaphysical threat. It relates to a trend in modernism:

This presents materialism as the view of courageous adults, who are ready to resist comforting illusions of earlier metaphysical and religious beliefs, in order to grasp the reality of an indifferent universe.

(Taylor 2007:574)

And it is certainly not far-fetched to say that the 'naturalisation of death' is indirectly linked to the knowledge that our sun, too, will one day die a natural death, which will mean the death of our planet (that will either combust or freeze, depending on whether our sun dies as a super nova or a white dwarf). Our expanding universe will also come to an end eventually by either expanding into oblivion or starting to contract anew.

Reflection on their own death is peculiar to humans. No other species does that as far as we know. Elias (1985:5) aptly observes: 'It is not actually death, but the knowledge of death, that creates problems for human beings'. In the Middle Ages and earlier times the brevity of human life and the horror of diseases and famine, as well as the role of the church (the idea of judgement - Taylor 2007:69), put death (and fear of death) at the centre of human consciousness (see Taylor 2007:65ff). All that has changed:

In this dispensation, although we fear the dead, we have no great reason to fear death. We don't welcome it, but it is part of the natural order of things, an appointed stage (Taylor 2007:66). ${ }^{11}$ Death is no longer a metaphysical, personified entity threatening us; at a horizontal level it is simply the loss of a loved one (see Taylor 2007:721). Traditional language and images are still used at funerals, but one cannot avoid an impression that it is very superficial, directed to children and the deceased's nearest and dearest purely for the duration of the funeral:

Conventional phrases and rituals are, of course, still in use, but more people than earlier feel uneasy using them, because they seem shallow and worn out. The ritual formulae of the old society, which made it easier to cope with critical life-situations such as this, sound stale and insincere to many young people; new rituals reflecting the current standard of feeling and behaviour, which make it easier to cope with the current crisis in life, do not yet exist.

(Elias 1985:24)

The Christian atonement model links (Christ's) death with reconciliation. No reconciliation is possible without (Christ's) death. Girard (1987) works the model out at a horizontal immanent level. For lack of space I cannot explain his entire model of mimetic desire and victimisation of the scapegoat, so I confine myself to the role of death. Girard (1987:412) adapts Freud's thinking to his own. The Freudian approach fits neatly into his system. Freud accentuates the reconciliatory aspect of death:

[I]t becomes clear that the reconciliatory aspect of mourning, the mourning that rejuvenates and invigorates all cultural activity, is in fact the essence of human culture... The proof that human beings identify all death with the reconciliatory victim and that the power of the sacred is called the cult of the dead, unlike the naturalistic concept of death, appears to underlie all other forms of religion.

(Girard 1987:80-81)

The death of all is linked with the death of the substitutive victim, hence death brings reconciliation and the community's future is possible because of the peace that follows the death. Consider,

11.Gore Vidal's novel Messiah (1956) is still an interesting example. It shows how in modernism the absence of death as a transcendent threat gave rise to a cult celebrating it as a natural event, eventually evolving into the dominant religion of the era. A few quotations illustrate the point: 'Death is nothing; literally nothing; and since, demonstrably, absence of things is a good; death which is no thing is good.. Death is neither hard nor bad. Only the dying hurts' (p.66): 'We're selling the truth a th is $[=$ the naturalness of death, CWdT] and that's something the the truth about life $[=$ the naturalness of death, CWdT $]$ and that's something that nobody, but nobody has ever done before' (p.101); 'Yes, Cave life will be wonderfu when men no longer fear dying. When the last superstitions are thrown out and we meet death with the same equanimity that we have met life. No longer w children's minds be twisted by evilgods whose fantastic origin is in those barbaric tribes who feared death and lightning, who feared life. That's it: life is the villain to those who preach reward in death, through grace and eternal bliss, or through dark revenge...' (p.101). 
for example, the notion that all the soldiers killed in a war are the sacrifice that had to be brought to secure peace. They are venerated (elevated to sainthood), for we owe the continuation of life to them

There is no culture without a tomb and no tomb without a culture; in the end the tomb is the first and only cultural symbol. The above-ground tomb does not have to be invented. It is the pile of stones in which the victim of unanimous stoning is buried. It is the first pyramid.

(Girard 1987:83)

Hence in Girard's model death fulfils a reconciliatory function at a horizontal immanent level. He rejects the concept of a sacred, transcendent, violent God and emphatically invokes Christ, who brings the violence of the offer cult (directed to the transcendent) to a close. Girard puts the accent on love, which could also be regarded as immanent transcendence. ${ }^{12}$

In a secular context the dilemma of death is replaced by the dilemma of life. Of course a focus on life in all its facets can lead to closed immanentism. But it can also lead to an approach of open immanentism or horizontal transcendence, as in the instance of secular spirituality (see Du Toit 2006:1251-1286). Taylor puts it thus:

What pushes us one way or the other is what we might describe and our over-all take on human life, and its cosmic and (if any) spiritual surroundings. People's stance on the issue of belief in God, or of an open versus closed understanding of the immanent frame, usually emerge out of this general sense of things.

(Taylor 2007:550)

He continues:

[W] could try to show how deep and powerful are the meanings of ordinary life, the satisfaction of love, of work, the enjoyment of the natural world, the riches of music, literature, art. This sense of the value of ordinary living is one of the constitutive elements of modern culture...

(Taylor 2007:711)

For modern, secularised people it is no longer a matter of some transcendent place and how to get there, but of how to live meaningfully (see Heidegger on coping).

I cannot elaborate further on how a focus on life itself includes horizontal transcendence, but merely look briefly at Žižek's notion of excess. The dilemma of life emerges in metaphors of non-fulfilment and excess. Life is marked by excess. Although basically a follower of Lacan, Žižek explains excess with reference to Freud's death drive.

Life loses its tautological self-satisfactory evidence: it comprises an excess which disturbs its balanced run. It becomes marked/ stained by an excess, containing a 'remainder' which no longer fits the simple life process. 'To love' no longer means to pursue the balanced process of reproduction, but to get 'passionately attached' or stuck to some excess, to some kernel of the Real, whose role is contradictory: it introduces the aspect of fixity or 'fixation' into the life process - man is ultimately an animal whose life is derailed through the excessive fixation to some traumatic Thing.

(Depoortere 2008:105n)

Žižek considers the drive unnatural:

The drive is an "excessive love of freedom,...which goes far beyond obeying animal instincts". The drive is "an uncanny unruliness that seems to be inherent in human nature'", "a wild unconstrained propensity to insist stubbornly on one's own will, cost what it may".

(Žižek quoted in Depoortere 2008:106)

That - the Thing - can be anything and is not associated with a specific object, as all human addictions prove. Here we are dealing with a human existential trait. Hence the Thing we

12.For a discussion of immanent transcendence in Girard's work, see Van Heeswijck 2005:82ff. aspire to remains with us always, irrespective of the fulfilment of any desire:

...the Thing, being the impossible/forbidden object in which desire would find a complete satisfaction, is nothing but its own absence: it is a hole in the centre of the symbolic order around which that order turns.

(Depoortere 2008:110)

The coming of Christ is the death of the Divine Thing (Depoortere 2008:12; Žižek 2006:42-44).

'The coming of Christ, however, traverses this fantasy: the Divine Thing does not exist and it is only its own absence, nothing but an empty space' (Depoortere 2008:113). But Christ's coming does not eliminate the transcendent: 'On the contrary, in Him, the transcendent realm becomes accessible as "immanent transcendence" (Depoortere 2008:114). In the context of immanent transcendence life is seen as problematic and humans as vulnerable and unfulfilled. ${ }^{13}$ The role of religion lies on the level of love, which may be described as horizontal transcendence.

There are other theological models that see the human need for religion in terms of a hiatus that people try to 'fill'. They experience themselves as bisected and look for their missing half to reach fulfilment. Is the experience of incompleteness a built-in evolutionary drive? After all, the ever-present drive to desire ensures constant change and the possibility that the species may benefit by successful new fulfilment of desire. Would we continually be looking for change, for improvement if we were self-sufficient? After every fulfilment we experience new incompleteness. The quest for fulfilment is life long, despite the many beacons along the way. ${ }^{14}$ This quest for fulfilment that Žižek calls excess is very evident in the present market economy. It has the potential to destroy all life. Žižek's portrayal of excess can certainly be related to sin, but then sin would not be a metaphysical entity.

The constant factor remains the human dilemma/predicament of non-fulfilment, suffering, fear of death - but with a difference. The cause of the problem ( $\sin$ ) and its denouement (transcendent bliss) are no longer taken as read.

\section{CONCLUSION}

Immanent transcendence permits a meaningful relationship between science and the impulses of the human mind. A new anthropology that takes account of scientific insight does not restrict the human person but merely wakes him/her up from her metaphysical dream world. The dread of secularised modern people is not that the bridegroom will come unexpectedly and catch them on the wrong foot (with no oil in their religious lamps), but that the bridegroom will not come at all and there will be no wedding hereafter. The flight into worldlessness (exploitation of the planet) to keep our metaphysical religious lamps burning has led to world renunciation (we are in the world but not of the world). We are facing a novel dilemma: there is literally no oil (resources) left to keep any lamp burning, and the condition for waiting for a new earth is to have the resources to survive the waiting. The technological carnival of boisterous planetary exploitation is over. In that context the term 'horizontal transcendence' in its negative mode is alarmingly true: the transcendent in the form of destructive forces comes from within, through human agency. Humankind may bring about its own Armageddon.

13.Van Heeswijck (2005:84) points out that Girard is a typical postmodern writer, 'who, by undermining the modern ideal of autonomy and by putting into relief human vulnerability and finitude, rejects a philosophy of subjectivity'.

14. One can cite many examples of the search for better understanding the design of better models in science and technology. Human sexuality also offers examples of this drive. The modern market economy with its apparently insatiable hunger for profit embodies the need at an almost universal level. 
It would be naïve to believe that secularised transcendence will spell the end of metaphysical certainties and normalisation of behaviour through dogma and morality. At most it is a way of handling transcendence. It is an acknowledgment that what can and cannot be said about transcendence must always be spoken in human language, images and understanding. To some extent that allows monitoring of language (ventriloquism for the transcendent) and claims (manipulation of believers).

Horizontal transcendence mirrors the evolutionary history of human thought without putting an end to creative possibilities. As an attitude to life horizontal transcendence makes it simpler to deal with the human condition in light of our techno-scientific knowledge and anthropologies, value systems and religious beliefs. It is open to handling scientific 'facts', human desire and lack of fulfilment responsibly with due regard to our understanding of human biology - leaving scope for the energy and commitment of belief. Immanent transcendence does not put an end to dualisms: the gulf between what is and what could be, between dream and reality, between immanentism and emergent transcendence remains too great for that. Probably it does not put an end to human violence, the will to power and desire either. But commitment to the planet inherent in horizontal transcendence is bound to temper desire, excess and activism that exalt the self at the expense of others and of nature. Our own insignificance, our planet's vulnerability, our total interdependence with life-giving systems are the immanent reality that we must bow to. The alternative is a transcendent vacuum.

\section{REFERENCES}

Appleyard, B., 1992, Understanding the present, Picador, London. Arendt, H., 1958, The human condition, University of Chicago Press, Chicago.

Bennett, G., Martinez, JH., Peters, T. \& Russell, J. (eds.), 2008, The evolution of evil, Vandenhoeck \& Ruprecht, Göttingen.

Blumenberg, H., 1983, The legitimacy of the modern age, MIT, Cambridge MA.

Blumenberg, H., 1995, 'Progress exposed as fate', in J. Faubion (ed.), Rethinking the subject, pp. 90-97, Westview Press, Oxford.

Dembski, W.A., 2006, Darwin's nemesis, IVP Academic, Leicester.

Depoortere, F., 2008, Christ in postmodern philosophy, T\&T Clark, New York.

Du Toit, C.W., 1984, Die metaforiese spreke oor God, Unpublished DD-thesis, University of Pretoria.

Du Toit, C.W., 2006, 'Secular spirituality versus secular dualism: Towards postsecular holism as a model for a natural theology', HTS Teologiese Studies/Theological Studies 62(4), 1251-1286.

Elias, N., 1985, The loneliness of the dying, Basil Blackwell, Oxford.

Elias, N., 1987, Involvement and detachment, The collected works of Norbert Elias, vol. 8, Blackwell, Oxford.

Firestone, C.L., 2007, 'Rational religious faith and Kant's transcendental boundaries', in K. Vanhoozer \& M. Warner (eds.), Transcending boundaries in philosophy and theology, pp. 77-90, Ashgate, Aldershot.

Girard, R., 1987, Things hidden since the foundation of the world, Athlone, London.

Heidegger, M., 1970, Wat is metafysica?, Lannoo, Utrecht.

Kauffman, S.A., 2008, Reinventing the sacred, Basic Books, New York.

McGrath, A.E., 2006, The order of things. Explorations in scientific theology, Blackwell, Oxford.

Myers, B., 2006, 'Alister McGraths's scientific theology', in A.E. McGrath, The order of things. Explorations in scientific theology, pp. 1-20, Blackwell, Oxford.

Pannenberg, W., 1993, Toward a theology of nature: Essays on science and faith, John Knox, Louisville.
Peacocke, A.R., 1993, Theology for a scientific age: Being and becoming - natural, divine and human, Fortress Press, Minneapolis.

Peat, F.D. \& Hiley, B.J., (eds.), 1987, Quantum implications: Essays in honour of David Bohm, Routledge and Kegan Paul, London.

Taylor, C., 2007, A secular age, Harvard University Press, Cambridge.

Van Heeswijck, G., 2005, ‘Every man has a god or an idol. René Girard's view of Christianity and religion', in P. Jonkers \& R. Welten (eds.), God in France, n.p., Peeters, Leuven.

Vidal, G., 1977, Messiah, Panther Books Ltd, London.

Weber, O., 1955, Grundlagen der dogmatik, Neukirchener, Göttingen.

Žižek, S., 2006, How to read Lacan, WW Norton \& Company, New York. 